\title{
PEDAGOGY
}

\section{МУЛЬТИКУЛЬТУРНА ОСВІТА: КОНЦЕПТУАЛЬНІ ЗАСАДИ}

\author{
кандидат педагогічних наук, доиент Прииляк Оксана Юрї̈вна \\ Украӥна, м. Тернопіль, Тернопільський національний педагогічний університет \\ імені Володимира Гнатюка
}

DOI: https://doi.org/10.31435/rsglobal_ws/30092019/6700

\section{ARTICLE INFO}

Received: 30 July 2019

Accepted: 19 September 2019

Published: 30 September 2019

\section{KEYWORDS}

multicultural education, multicultural environment, factors and principles of multicultural education, model of multicultural education.

\begin{abstract}
The article describes the essence of multicultural education, which in the modern world acquires the leading concept of the unity of world cultures, the search for unifying components and ways of their realization. The article deals with the interpretation of multicultural education, new approaches to the organization of multicultural professional education, factors and principles of multicultural education, model of multicultural education are disclosed.
\end{abstract}

Citation: Пришляк О. Ю. (2019) Multykulturna Osvita: Kontseptualni Zasady. World Science. 9(49), Vol.1. doi: 10.31435/rsglobal_ws/30092019/6700

Copyright: (C) 2019 Пришляк О. Ю. This is an open-access article distributed under the terms of the Creative Commons Attribution License (CC BY). The use, distribution or reproduction in other forums is permitted, provided the original author(s) or licensor are credited and that the original publication in this journal is cited, in accordance with accepted academic practice. No use, distribution or reproduction is permitted which does not comply with these terms.

Вступ. У сучасних умовах глобалізаційні процеси торкаються всіх сфер життя та актуалізують проблему модернізації освіти у загальнопланетарному масштабі. Це добре усвідомлюють у розвинутих країнах світу, наслідком чого постало розроблення загальнонаціональних освітніх програм і проектів, таких як «Освіта Америки XXI століття», «Національний навчальний план» (Велика Британія), «Освіта майбутнього» (Франція), «Модель освіти XXI століття» (Японія).

У доповіді міжнародної комісії ЮНЕСКО, присвяченій проблемам розвитку освіти, визначено орієнтири переосмислення іiі стратегічного призначення в сучасних умовах. Сьогодні зазнає переосмислення цільове призначення освіти у контексті викликів загальнопланетарного масштабу; констатовано, що мета і призначення освіти полягає в гуманізації і стабілізації суспільних відносин. Цю ідею відображено в основних міжнародних документах, зокрема у Всесвітньому звіті ЮНЕСКО «Інвестиції в культурне різноманіття та міжкультурний діалог» (2009 р.) підкреслено, що культурна грамотність стала життєвим орієнтиром для сучасного світу [17]. У 2011 році, Рада Європи опублікувала доповідь «Жити разом: поєднання різноманітності та свободи в Свропі XXI століття» (Living together. Combining diversity and freedom in 21st-century Europe, 2011) [14]. У січні 2016 року ЄС прийняв резолюцію «Міжкультурний діалог, культурне різноманіття та освіта» («Intercultural dialogue, cultural diversity and education»), в якій вказано на важливість викладання міжкультурного діалогу, навчання міжкультурної компетентності, що є одними 3 найбільш дієвих інструментів управління конфліктами, та формування більш глибокого почуття власної ідентичності. Учителі, батьки, громадські та правозахисні організації визнані ключовими учасниками процесу мультильтурного навчання. Без сумніву, цей політичний документ прийнятий $з$ метою надання більшої політичної ваги мультикультурній освіті як інноваційному концептуальному підходу і засвідчує прихильність $Є С$ до ідеї інтеграції різноманітності, сприяння багатомовності та реалізації міжкультурного діалогу [17]. 
Власне тому у XXI ст. все більшого значення набуває переосмислення концептуальних засад освіти у контексті мультикультурності сучасного буття. Проблеми мультикультурної освіти перебувають в полі зору як зарубіжних (Дж. Бенкс, Е. Кругли-Смольска, В. Кімлічка, К. Слітер [22], К. Грант [15], М. Гібсон [16] так і українських (І. Бахов, І. Білецька, Я. Гулецька [4], О. Гуренко [5], Р. Кравець [7], С. Лук'янчук, О. Слоньовська, Л. Хомич, Л. Султанова, Т. Шахрай [8] дослідників.

Результати дослідження. Американський дослідник Дж. Бенкс вважається засновником мультикультуралізму в освіті; саме він вперше розробив концепцію мультикультурної освіти (multicultural education). На думку Дж. Бенкса метою мультикультурної освіти $є$ сприяння у побудові відкритого суспільства, в якому будуть створені рівні можливості для всіх етносів щодо реалізації їх соціальних і культурних потреб [11, 39-43].

У міжнародній енциклопедії освіти поняття «мультикультурна освіта» трактується як «педагогічний процес, в якому репрезентуються дві або більше культур, що відрізняються за мовною, етнічною, національною або расовою ознаками» $[19,273]$.

У працях багатьох зарубіжних дослідників зустрічаємо різноманітні трактування суті мультикультурної освіти та чинників, що зпричинили іiі виникнення. Так, К. Грант вважає, що розвитку мультикультуралізму як суспільно-культурного явища сприяли такі провідні чинники соціально-етнічного характеру як міжкультурний рух, міжгруповий рух, рух за рівний доступ до освіти для всіх етнічних груп та рух за громадянські права $[15,2-3]$. Активний прихильник мультикультурної освіти Г. Бейкер стверджує, що в США мультикультурна освіта з'явилася як необхідність цивілізованого врегулювання міжнаціональних і расових конфліктів у цій країні $[10,76]$.

Дж. Бенкс на основі аналізу історичного контексту становлення i розвитку мультикультурної освіти у США виокремив такі провідні етапи цього процесу:

- перший: виникнення і становлення етнічного навчання, суть якого полягала у діяльності педагогів із залучення до освітніх програм комплексу знань про етнічні меншини та розробка теорії етнічного навчання;

- другий: етап боротьби за створення багатоетнічної освіти, реалізація якого передбачала створення для учнів і студентів етнічної меншості умов отримання рівноцінної освіти;

- третій етап вчений пов'язує із активізацією студентів - представників етнічних меншин у боротьбі за включення знань історичного і культурологічного характеру про свої етнічні групи у навчальні плани;

- четвертий $є$ етапом оформлення мультикультуралізму в чітку теорію $[11,120]$.

Для України, як і для більшості країн світу, які працюють над упровадженням концепції мультикультурної освіти, певний науковий інтерес становлять принципи мультикультурної освіти, розроблені Дж. Бенксом [12]. На думку дослідника провідними принципами мультикультурної освіти слугують такі провідні положення:

- мультикультурну освіту слід розглядати як процес;

- перш ніж розпочинати реалізацію мультикультурної освіти, необхідно домогтись усвідомлення учасниками цього процесу своєї етнічної ідентичності;

- полікультурний підхід до організації навчання має охоплювати всю його організацію;

- у кожному суспільстві має функціонувати свій варіант мультикультурної освіти, що відображатиме його специфіку;

- реалізації мети і завдань мультикультурної освіти має передувати спеціальна підготовка як вчителів, так і батьків;

- упровадження мультикультурної освіти не має обмежуватися певними часовими рамками;

- ідея мультикультурної освіти має знаходити всебічне відображення у змісті навчальних програм [12, 9-10].

Для усіх країн, які прагнуть упроваджувати концепцію мультикультурної освіти у процес професійної підготовки майбутніх фахівців, значний інтерес представляють підходи до організації мультикультурної професійної освіти у США, які окреслила і схарактеризувала американська дослідниця М. Гібсон $[16,2]$. Дослідницею окреслено такі п'ять основних підходів до організації цього процесу:

1. Виховання культурного різноманіття. Мета мультикультурної освіти полягає у вирівнюванні освітніх можливостей для студентів з різних культурних осередків.

2. Виховання толерантного ставлення до інших культур, суть якого полягає у формуванні в студентів шанобливого ставлення до інших культур, толерантного ставлення до права студентів бути різними у своїх етнокультурних особливостях. 
3. Виховання культурного плюралізму, мета якого полягає у збереженні і розвитку в суспільстві полікультурного плюралізму.

4. Міжкультурне виховання. На думку дослідниці мультикультурна освіта покликана сприяти формуванню толерантності та міжкультурної компетентності $[16,2]$.

Ми поділяємо наукову позицію дослідниці стосовно того, що власне такі підходи дозволяють освіті біль повноцінно виконувати функцію передачі, а, отже, збереження i збагачення культурної інформації.

У Великій Британії проблема обгрунтування концептуальних засад міжкультурної освіти і технологій ії реалізації є предметом дослідження дослідників (Е. Саід [23], М. Бірам [13], Е. Джонс [18], Парек [21], Д. Кілік) та інших. У працях дослідників стверджується, що у Великій Британії зростає популярність концепції мультикультурної освіти як у суспільстві в цілому так і серед освітян.

Значний науковий інтерес для науковців і практиків мультикультурної освіти $є$ модель організації навчання, розроблена дослідником Е. Саідом [23]. Згідно з цією моделлю процес навчання учнів чи професійної підготовки майбутніх фахівців має передбачати такі послідовні етапи:

— ознайомлення з міжкультурними функціями різних мов як засобом міжнаціонального спілкування;

- усвідомлення причин та способів культурно-історичної взаємодії представників різних етносів;

- актуалізація міжкультурних форм спілкування в культурно-мовних спільнотах;

- формування конкретних уявлень про різні мови і їх роль у житті цих етносів;

- розвиток здатностей до компенсаторної багатомовності у випадку контактів із незнайомим мовним середовищем [23, 84].

Німецький дослідник Г. Томас вважає, що мультикультурна освіта може бути ефективною лише тоді, коли для індивіда характерним стає толерантне ставлення до людейпредставників інших культур, прагнення зрозуміти їхню систему духовно-культурних цінностей, інтегрувати результати ознайомлення з ними у власну систему цінностей [24].

Вважаємо за доцільне зауважити, що відносно способів реалізації міжкультурної освіти у міжнародній практиці значного поширення набула наукова позиція фінського вченого Дж. Летонена, який стверджує, що для успішної соціальної і професійної взаємодії 3 представниками іншого етносу бажано знати їх мову, історію їх країни, мати певний запас знань про їх суспільство і культуру [20].

Для України, яка прагне влитися в європейський освітній і економічний простір, важливо творчо запозичати прогресивні ідеї зарубіжного досвіду щодо перебудови й модернізації системи освіти у контексті сучасних викликів. Все більше число не лише науковців, але й освітян, державних діячів починають розуміти важливість упровадження ідей мультикультурної освіти, пріоритетними завданнями яких $є$ формування людини у дусі загально цивілізаційних цінностей, готовності і здатності жити і здійснювати професійну діяльність у полікультурному середовищі. На законодавчому рівні це відображено в основних державних документах, зокрема Стратегії сталого розвитку «Україна 2020» (2015 р.), Національній стратегії розвитку освіти в Україні на період до 2021 року (2013 р.), законах України «Про освіту» (2017 р.), «Про вищу освіту» (2014р.), які орієнтують діяльність освітніх інститутів суспільства на підготовку особистості до життя і діяльності у мультикультурному середовищі.

Ми поділяємо наукову позицію українських дослідників (О. Гуренко, Р. Кравець, А. Колодій, О. Слоньовська та ін.) стосовно того, що: мультикультурність в сучасних умовах доцільно трактувати як принцип організації суспільства, який вимагає врахування наявності у ньому різноманітних ціннісних і духовних уподобань та пріоритетів, що відображають світосприйняття різних етнокультурних прошарків суспільства. Так, А. Колодій зазначає, що мультикультуралізм відображає новий підхід до культурно-освітньої політики, який підтримує i стимулює право людей різних національностей зберігати свої етнокультурні особливості, а державу зобов'язує їх захищати [6].

Увагу привертає і наукова позиція О. Слоньовської стосовно того, що в широкому трактуванні суть мультикультурної освіти доцільно розуміти як «нову методологію, яка прагне осягнути психологічні, антропологічні, соціальні, економічні, історичні, політичні й культурні показники для виокремлення та актуалізації взаємозв'язків з гуманітарними дисциплінами в процесі викладання кожного навчального предмету» [9, 9-10].

I. Бесарабова вважає, що мультикультурну освіту слід трактувати як особливий спосіб світосприйняття, концепцію свободи особистості від національної обмеженості, прагнення до 
рівності різних етносів; освітню реформу, яка покликана внести суттєві зміни в навчально-виховний процес, 3 тим, щоб він відповідав вимогам сучасного полікультурного суспільства [2, 97-99].

Українські дослідники Л. Султанова, Л. Хомич, Т. Шахрай [8] стверджують, що «основоположні ідеї теорії мультикультурної освіти складають філософські, культурологічні, соціологічні та педагогічні положення, сформульовані в межах теорії полікультурності, категоріальний апарат якої характеризується недостатньою розробленістю ... відповідних понять: «полікультурна», «мультикультурна», «багатокультурна», «транскультурна», «кроскультурна» освіта тощо» $[8,105]$.

В. Болгаріна та I. Лощенова трактують поняття мультикультурної освіти як такої, для якої ключовим поняттям $є$ культура як загальнолюдське явище; це засіб допомоги особистості в подоланні шляху від засвоєння етнічної, національної культури до усвідомлення спільних інтересів народів у їхньому прагненні до миру, злагоди, прогресу через культурний розвиток» $[3,2]$.

I. Бахов визначає «мультикультурну освіту як процес цілеспрямованого, планомірного формування й розвитку світогляду, переконань і почуттів особистості, що грунтується на визнанні багатоманітності культур, збагачує іiі почуття, формує особливе ставлення до навколишнього світу і людей у ньому та супроводжується сприйманням й осмисленням життєво важливих парадигм буття, перетворенням зовнішніх культурних смислів у внутрішній морально-етичний світ» $[2,43]$.

Аналіз досліджень вчених (І. Бахов, І. Білецька, В. Бойченко, Я. Гулецька, О. Гуренко, Р. Кравець, О. Шевнюк та ін.) дозволяє сформулювати такі провідні принципи функціонування мультикультурної освіти:

- принцип гуманізму (сприяє вихованню високоморальної особистості 3 гуманістичною установкою);

— принцип діалогу культур як засіб їхнього зближення;

— принцип культурологічного підходу (дозволяє сформувати полікультурний світогляд);

- принцип пріоритетності в навчанні етичних і моральних цінностей знань.

Висновки. У відповідь на виклики, що постали перед сучасною Європою 3 необхідності забезпечити належне управління культурним розмаїттям, європейськими країнами, міжнародними організаціями, об'єднаннями, союзами, постійно проводяться численні заходи щодо пошуку нових підходів до питань налагодження міжкультурного діалогу, який важливий для управління культурним розмаїттям в багатокультурному середовищі. Налагодження цього діалогу неможливе без впровадження мультикультурної освіти, котра в сучасному світі набуває обрисів провідної концепції єднання світових культур, пошуку об’єднавчих складових та способів їх реалізації.

В Україні, яка переживає складний період трансформації суспільства і системи суспільних відносин, науковцями і практиками приділяється увага теоретичному осмисленню і розробці технологій упровадження концепції мультикультурної освіти. На думку дослідників мультикультурна освіта в сучасних умовах покликана: органічно поєднувати виховання національної самосвідомості, патріотизму із почуттям пошани до інших культур; сприяти вирішенню завдань формування глибо освіченої особистості, яка оволоділа культурним багатством нації, спроможної до адаптації в інших полікультурних середовищах; створити для національних меншин максимально сприятливі умови для якісної освіти; забезпечити формування позитивних ціннісних орієнтацій у світлі ознайомлення із досягненнями світової культури; сприяти формуванню культурної ідентичності, любові до національних культурних цінностей; забезпечити в процесі викладання гуманітарних дисциплін поєднання національних i різнокультурних компонентів; сприяти формуванню світогляду, органічними елементами якого є культурні цінності та культурні особливості різних націй.

Базуючись на вищезазначеному можна стверджувати, що мультикультурна освіта в сучасному світі набуває обрисів провідної концепції єднання світових культур, пошуку об'єднавчих складових та способів їх реалізації.

\section{ЛITЕРАТУРА}

1. Бахов І. С. Тенденції розвитку полікультурної освіти у професійній підготовці фахівців Канади і США: монографія / Іван Степанович Бахов. - К.: Центр учбової літератури, 2018. - 420 с.

2. Бессарабова И. С. Современное состояние и тенденции развития поликультурного образования в США: дисс. ... д-ра пед. наук: 13.00 .01 / Бессарабова Инна Станиславовна. - Волгоград, 2009. - 492 с.

3. Болгарина В. Культура і полікультурна освіта / В.Болгаріна, І.Лощенова // Шлях освіти. - 2002. - №1 - С.2-6.

4. Гулецька Я. Г. Полікультурна освіта студентської молоді в університетах США : дис. ... канд. пед. наук: 13.00.01 / Гулецька Яна Гаврилівна. - К. : Київський національний університет імені Тараса Шевченка, 2008. -262 с. 
5. Гуренко О. I. Полікультурна освіта в Україні: до сутності поняття / О.І.Гуренко // Збірник наукових праць Бердянського державного педагогічного університету: Педагогічні науки. - 2009. - №1. - С.95-103

6. Колодій А. Американська доктрина мультикультуралізму і етнонаціональний розвиток України / А.Колодій // Агора. Випуск 6: Україна і США: взаємодія в галузі економіки, культури і науки. 2008, C.5-14. - [Електронний ресурс] : Режим доступу : http: // political-studies. com/?p=578.

7. Кравець Р. А. Теоретичні і методичні основи полікультурної освіти майбутніх фахівців аграрної галузі дис. ...д-ра. пед наук 13.00.04 / Р.А.Кравець. - Хмельницький, 2018. - 577 с.

8. Полікультурна освіта в контексті загальнокультурного розвитку особистості педагога: монографія / Л.О.Хомич, Л.Ю.Султанова, Т.О.Шахрай. - Кіровоград: Імекс-ЛТД, 2014. - 212 с.

9. Слоньовська О. Б. Полікультурна освіта майбутніх учителів гуманітарних дисциплін у вищих навчальних закладах Канади: дис. ... канд. пед. наук : 13.00.01 / Слоньовська Оксана Богданівна. Житомир, 2011. - 256 с.

10. Baker G. Multicultural Imperatives for Curriculum Development of Teacher Education / G. Baker // Jornal of Research And development in Education/ - 1977. - №11(1). - P.70-83.

11. Banks J. A. Multicultural Education: Foundations, Curriculum and Teaching / James A. Banks/ - University of Washington. $-384 \mathrm{p}$.

12. Banks J. A. Teaching ethnic studies: Concepts and strategies / J.F.Banks/ Washington, DC: National Council for the Social Studies, 1973. - $232 \mathrm{p}$.

13. Byram M. Bicultural and trilingual education : the Foyer model in Brussels / M. Byram, J.Leman. Clevedon. England: Multilingual Matters Ltd, 1990. - 158 p.

14. Council of Europe. The Report of the Group of Eminent Persons of the Council of Europe. Living together. Combining diversity and freedom in 21st-century Europe, 2011. - Режим доступу: https://rm.coe.int/16806b97c5 (дата звернення 1.09.2019). - Назва з екрана.

15. Grant C. A. The Evolution of multicultural Education in the United States: A Journey for human Rights \& social Justice [Electronic resource] / C.A. Grant/ - URL: http: //www.iaie.org/download/turin_paper_grant.pdf. - назва 3 титулу екрану)

16. Gibson M. Approaches to multicultural education i the United States: some concepts and assumptions //Anthropology and Education Quarterly - Vol. 15. - No. 1, Special Anniversary Issue: Highlights from the past, 1984. - P.94 - 120 .

17. European Parliament. Committee on Culture and Education. Motion for a European Parliament Resolution on the role of intercultural dialogue, cultural diversity and education in promoting EU fundamental values. - Режим доступу: http://www.europarl.europa.eu/doceo/document/A-8-2015-0373_EN.html?redirect (дата звернення 1.09.2019). - Назва з екрана.

18. Jones E. Internationalisation of the curriculum / Jones E., Killick D. // In: Jones E., Brown S. (eds) Internationalising Higher Education. - London: Routledge, 2007. - P.110.

19. International Dictionary of Education. Vol.7. - Oxford, 1994. - 3963 p.

20. Lehtonen Jaako. Globalization, National Cultures, and the Paradox of Intercultural Competence. Available from: http: // viesti, Jyu. fi / Iaitos / Lehtonen / globalization. Html. - Retrieved: 02.12.2003.

21. Parekh B. The Future of Multi-Ethnic Britain: The Parekh Report. - TheRunnymede Trust, 2002. - 417 p.

22. Sleeter C. Multicultural Education Critical Pedagogy and the Politics of Difference / Sleeter C., Mclaren P. - Albany: SUNY Press, 1995. - 465 p.

23. Said E.W. Culture Imperialism / E.W.Said. - London: Vintage Books, 1993. - 260 p.

24. Thomas H. Interkulturelles Lernen im Shculeraustausch. - Saarbrucken u. Fort Lauderdale, 1988. - P.66. 